\title{
A Neo-realist American China Foreign Policy
}

\author{
Huaiping Zhang \\ Foreign Language Studies, \\ Jiangsu University of Technology \\ Changzhou, PRC \\ zhp98147@jsut.edu.cn
}

\begin{abstract}
The paper approaches the future trend of American China policy. It first traces back to American foreign policy at different stages. Then it turns to the in-depth study of American China policy and the future of American China policy. The United States' foreign policy has a direct impact on many aspects of the development and the future pattern of the world. To predict the future China policy that the United States will adopts is beneficial for China to make a right choice at a right time. How China will develop and what a status it will take in the future world is conditioned by American China policy. American China foreign policy has changed with the rapid rise of China. While the United States benefits from China's development, it tries to curb China's rise. Containment and cooperation are still the keystone of American China policy. The possibility that China and the United States will have violent conflicts is less and less as the two have had stable diplomatic relations for over 30 years and China seeks common interests with America in many sensitive issues. The future of Sino-US relations is hopeful.
\end{abstract}

\section{Keywords- hegemony; containment; cooperation; policy}

\section{INTRODUCTION}

Henry Kissinger thought that it was not feasible for America to carry out "containment" policy on China, as China is an influential country in Asia. He claimed that the United States should strengthen its alliance with Japan militarily while strengthening steady political and economic tie with China.

20th century British realist scholar Edward Karl and American realist master Hans Morgenthau advance that the study of international politics is gradually making for the scientific development and gradually evolves into a new field of social science. After Kenneth N. Waltz launched his tripod work The International Political Theories, the study of international politics has gradually become more mature and rigorous. At the same time, the theory of international politics Waltz created is called "neo-realism" by the academics.

Neo-realism claims that the eternal theme for a country is to survival and competition no matter what happens to the international situation. Military power is still the key for every nation to grasp international power and improve international influence [1].

Neo-conservatism is not willing to see the decline of American overseas hegemony. They think that the future of America and the capitalist world depend on American revival and growth in military power. Close relation with China will endanger the interests of America and its alliance.
They advocate "China threat theory" to curb China's development strategically.

Since George W. Bush became President of the United States, the international situation has undergone unprecedented and profound changes. In the meantime, the United States has also experienced a high-profile foreign policy and a major adjustment.

At the beginning of the Bush administration, the overall focus of foreign policy were sparing no effort to maintain and consolidate the hegemony of the United States, and even did not allow the emergence of any regional hegemony, in which the United States needed to maintain an adequate military strength for regional intervention, hoping to maintain hegemony as long as possible. And his predecessor, Bill Clinton was aware of the reality that the United States would have only 15 years of opportunity.

Bush entered the White House, brought about "9.11" incident, and then launched the Iraq War. The United States was bogged down in Iraq War, as it vigorously implemented the "neo-conservatism," and "unilateralism," causing the United States and the world to undergo far-reaching changes.

American national security has gone beyond the international standards recognized by the United States, as it has the right to take the "pre-emptive" military attack with the excuse of self-defense, question the values and ideology of other countries, intervene in the internal affairs of other countries in the name of "democracy", and subvert the regime of other countries for so-called "reason." "Unilateralism" is "Bush Doctrine", a concentrated expression. The Iraq war not only offended and alienated many of the Arab Islamic countries, but expanded and strengthened Iran's influence, Iraq's enemy, posing a more difficult problem to the United States [2].

Another serious consequence of the Iraq War is that it makes the United States and its traditional allies of the strategic partnership difficult to repair a rift; and a number of other countries fear the high-handed acts of the United States and will take corresponding preventive measures [3].

The main means of George W. Bush is to implement military intervention and global hegemony. But military superiority and hegemony should not translate into a longterm or permanent practice. The United States suffers a fundamental loss as more people recognize that the United States military strength will not solve all the problems and a variety of challenges it will face. The United States' military is not omnipotent; it doesn't deserve fear.

The United States is always stressing its national interests, and implements the "all-directional diplomacy." The world is "a multi-polar world". Iran, North Korea and other countries 
withstand the pressure from America and develop their nuclear energy in spite of the fact that the United States takes a hard-line stance. Venezuela, Cuba and other countries are active in the Latin American region. Russia harshly condemns American foreign policy on such issues as antiballistic missile, showing no sign of weakness.

American neo-conservatism designed President Bush's foreign policy, overestimated their own strength and underestimated the difficulties they might encounter. It made a fatal error and went against the desire of people who wanted peace and development of the times, and was doomed to fail. It will not be easy for the next administration to remove the "Bush Doctrine" strategic errors.

\section{THE AMERICAN FOREIGN POLICY AFTER THE COLD WAR}

After the Cold War, the United States has become the world's sole superpower and enjoys the position of hegemony in the world. The United States aims to dominate international politics.

American foreign policy has an important impact on the vast majority of countries and the world constitute. The United States relies on its superior national strength, and always takes the post-Cold War unilateralism policy. The policy of unilateralism not only seriously hurts the strategic interests of its political enemies, but also hurts the majority of small and medium-sized countries or even its military ally's strategic interests. The most typical example is that the U.S. Congress refused to ratify the "Comprehensive Nuclear Test Ban Treaty"(CTBT) in 1999 and the United States seeks to amend the "ABM Treaty" (ABM) policy. More than 100 European members of NATO and the Government of Japan have criticized the U.S. Congress act." [2] The First Committee of the United Nations disarmament and international security affairs at the 54th UN General Assembly was voted by 54 votes in favor, 4 against and 73 abstentions, and adopted the "Preservation of and Compliance with (ABM Treaty) Resolution". The act expressed strong discontent to the United States. [3]

The Allies of the United States such as Germany and the United Kingdom had expressed concern about the unilateralist act of the United States. [4] Other powers led by Russia are against American hegemony.

The proposal of UN General Assembly concerning the maintenance of "ABM Treaty" was from Russia, cosubmitted by China and Belarus, and America had to stand the confrontation from all the other members of the United Nations. NATO's eastward expansion created conflict between the United States and Russia so that all the small countries in Europe and much of the former Soviet republics have had to express support for the proposal. This proposal is directly related to the vital national interests of these small and medium-sized countries. "Strategic interests of Japan and Europe are what make the United States object to the revision of the World Trade Organization rules by means of American hegemonic position. The majority of the members also raised a number of objections at the World Trade Organization meeting in Seattle that ended in 1999." ${ }^{[5]}$
In the post-Cold War period the United States set up a system of hegemony, which is different from what there has ever been in history. The difference is that the United States' hegemony not only entirely relies on military strength to impose its own will, but wants to set up a US-led system of institutionalized hegemony. "The United States is the first country with written constitution, whose long-term political and constitutional thoughts have a profound impact on the formulation of its foreign policy." [6] American "National strategy for the new century security report" in 1999 made it clear: "We should support international institutions and organizations, gain their support to help the United States to assume responsibility to lead the world." [7]

\section{THE AMERICAN CHINA POLICY IN THE PAST}

\section{A. New China and Us Relations}

The Chinese Communists finally won the civil war. The common strategic interests between PRC and the United States were formed in the new conditions. Their common strategic interests have two aspects: (1) both the need to prevent the occurrence of a third world war; (2) both sides are required to establish diplomatic relations. However, because of the strategic thinking dominated by ideology, China and the United States were not fully aware of the importance of their common strategic interests. In addition, the gap in the national strength between China and the United States was so wide that the United States estimated that the new China's demand for its strategic interests was high; it took arrogant prejudice to Sino-US strategic needs, and its psychological assessment was in imbalance.

Actually, the United States seriously considered setting up diplomatic relations with new China and went into the specific treaty discussions with the Chinese Communists. Although the United States supported the KMT in Chinese civil war, but it was not difficult to establish the diplomatic relations with the Chinese Communists at the time, but the pre-condition was that the United States stopped aid to the Chiang Kai-shek and severed diplomatic relations with the KMT. On May 10, 1945, Mao Zedong instructed Huang Hua and said: "If the United States and our Government are prepared to consider the establishment of diplomatic relations, the U.S. government should stop aid to the KMT's action and cut off contact with the remnants of the Kuomintang reactionary forces, and do something beneficial to the Chinese people."[8]

In agreement with the Soviet Union ideologically, China has adopted a "one-sided" policy, so the United States adopted a policy of isolating China. When the Korean War broke out, the two sides decided to enter the war immediately. The United States was involved in the all-out war for its strategic interests and did not give sufficient consideration for China. The arrogant America underestimated the "military demarcation line" set by China, endangering China in an all-out war.[9] After the Korean War ended, the scholars of China and the United States believe that China and the United States were on a wrong war in the wrong place at the wrong time. 
Summarizing the Sino-US relations during this period, we can note that the United States is only aware of the common strategic interests of both sides, which is not enough to promote bilateral strategic cooperation.

\section{B. In the Early 1970 s}

After the outbreak of the Korean War, the common strategic interests between China and the United States no longer existed. Theoretically speaking, the common interests between China and the U.S. are still existent. If common interests are too insignificant, or the conflict far outweighs benefits, people will not consider the existence of common interests. After the Korean War broke out, Sino-Soviet relations came to a complete breakdown in the 1960s, and the common interests between China and the United States emerged.[10]

China and the United States could work together to curb the expansion of the Soviet Union and hold the Taiwan issue in abeyance, but the two sides had many differences on the Taiwan issue and could not rapidly develop strategic cooperation. Despite the Sino-US summit talks, the question of Taiwan was still hindering the normalization of Sino-US relations, not to mention to establish formal diplomatic relations.

On January 27, 1973, the United States and Vietnam signed the peace agreement to end Vietnam War, followed by the United States beginning to withdraw troops from Vietnam, which had created new conditions for the further development of Sino-US strategic partnership. Again in February the same year Henry Kissinger visited China, and Mao Zedong interviewed Henry Kissinger. Both sides expressed the desire to accelerate the normalization of diplomatic relations. Henry Kissinger and Mao Zedong came to consensus that both sides faced the same danger and might sometimes adopt different methods but with the same goal. Mao Zedong said that as long as we did not harm you, and you did not harm us, we can join hand in hand for the ultimate goal.

November 10, 1973 Secretary of State Henry Kissinger visited China for the 6th time, and he talked with Mao Zedong and Zhou Entail. China and the United States reiterated Sino-Us Joint Communiqué. America won’t seek hegemony in the Asia-Pacific region .The common strategic interests of China and the United States have been extended to the scope of the world. "By the end of 1973, the U.S. military withdrew 3000 soldiers from Taiwan and the U.S. military troops stationed in Taiwan would be reduced by one third." [11] The normalization of Sino-US relations was quickened with the subsequent creation of the conditions.

China and the United States were aware of their common strategic interests, but the foundation was to reach a consensus on the Taiwan issue.

\section{THE Future OF AMERICAN CHINA POLICY}

\section{A. China Threat Theory}

The Critics of U.S. China policy has been enjoying unprecedented attention lately. Between those who want to be tough with China and those who want to be cooperative, the second-term Clinton administration sought to consolidate and expand complicated cooperative Sino-U.S. relations. Advocates of nearly every stripe had a hand in distorting China's impact on American interests and Washington's policy since the late 1980s. Many made their efforts to persuade America to abandon engagement with China and follow a policy of "containing" and "China threat". An example of the hostile hyperbole that has become quite common is the statement of the Center for Security Policy of June 9(1997) from the Washington-based William J. Casey Institute: "The nature of the threat posed by China is in key respects of a greater magnitude and vastly greater complexity than that mounted by the Soviet Union at the height of the Cold War."[12]

If we step back and evaluate the issues fairly, two truths come clear: China is not a "rogue state", and U.S. policy has made important gains in affecting Chinese behavior over a wide range of issues bearing on important American interests. The two points may be demonstrated by looking at military and economic dimensions of the bilateral relationship, as well as at the heated debate over China's human right practices.

The most serious Chinese challenge to the United States is its potential military power. Chinese economy is growing and its ability to increase defense spending is growing with it. But advocates of containing China vastly overestimate Chinese power and underestimate their own.

A larger Chinese economy will not necessarily lead to a greater military power. China can import weaponry, but sustained improvement in military capabilities will require indigenous defense modernization. The need of the People's Liberation Army to import Russian equipment is telling. Buying from Russia is a quick and relatively inexpensive way for China to equip its forces with materials far superior to indigenous products. But this should not be particularly upsetting to U.S. policy planners, whose forte is the destruction of Russian equipment with remarkable speed and skill. Moreover, China lacks in the basic ability to maintain Russian equipment. It now requires extensive Russian assistance to repair many of its recently acquired SU-27s and its Kilo submarines. [13]

China has developed a limited number of more modern destroyers, but it is decades away from being able to manufacture and deploy a first-generation, limited capability aircraft carrier. The PLA (People's Liberation Army) lacks in the ability to conduct sustained military operations more than 100 miles from the Chinese shoreline. China is a formidable land power, but in maritime Southeast Asia, where U.S. interests are most at stake, China is militarily inferior even to such countries as Singapore and Malaysia.

In the end, China may succeed in modernizing its military. But it may fail, too. Economic and technological modernization is a precarious enterprise. As an export processing zone for the advanced industrial countries, China has succeed in raising living standards and its GNP, but this is a far cry from developing the economic and technological capabilities to equip a twenty-first century military force [14]. 
U.S. military supremacy is so overwhelming that Washington has the luxury of being able to observe Chinese technology development and weapons production before adopting countervailing policies. Not only is the U.S. defense budget greater than the combined defense budgets of the next six largest competitors, but U.S. technology and weapons modernization are advancing so rapidly with each passing day. And despite its strenuous efforts, China's technological and military capabilities are losing ground rather than catching up with those of the United States.

Politically, too, the American alliance system in Asia is superior to anything Chinese can hope to have. Logistically, the U.S. alliance with Japan and its access to basing facilities throughout the region give the United States an enormous advantage. Diplomatically, China is increasingly viewed in the region as a problem to be managed, while the United States is seen as a relatively disinterested power-broker whose aims are compatible with regional peace and prosperity for all.[15]

A potential Chinese alliance with Burma and Russia can hardly offset the U.S. relationship with Japan, South Korea, Australia, and the maritime states of Southeast Asia (including, still, the Philippines). With such logistical and diplomatic superiority, current U.S. defense spending and weapons acquisitions are already more than sufficient to hedge against China's potential development of advanced military capabilities.

\section{B. Taiwan Issue}

It is true, nevertheless, that despite China's limited military capabilities, the PLA can use military force effectively and is not hesitant to do so. The PLA has been part of every major crisis in East Asia since 1949. It has the ability to disrupt regional stability and inflict considerate costs on U.S. interests. Clearly, the most serious conflict in U.S.-China relations remains to be the Taiwan issue, and it is irresolvable in principle [16]. Beijing wants unification under PRC (People's Republic of China) and reserves the right to use military force to bring it about. The United States insists on Taiwan's right to make its choices free from military pressure.

Even if the Taiwan issue is intractable in principle, it can be managed so that U.S.-China conflicts of interests do not disrupt cooperative relations; this has clearly been the U.S. experience from the early 1970 s to the early 1990s. U.S. policy has guaranteed Taiwan's security, and more important, has provided an environment in which Taiwan develops a prosperous economy and a flourishing democracy [17]. These successes form the bedrock of Taiwan's diplomatic autonomy, and the only concession Washington has to make to help Taiwan achieve so is to refrain from actions that could be interpreted as support for formal Taiwan independence.

Equally important, Washington's multifaceted assistance to Taiwan did not make improved relations with China impossible. Diplomatically, what seemed a zero-sum game between Taiwan and the mainland turned out not to be zerosum at all for American policy. Mutually beneficial economic relations and cooperation in maintaining regional stability on a wide range of issues were also important. China today still wants to avoid heightened U.S.-China adversarial relations, much less a literal fight with the United States over Taiwan. Considering this, Washington can continue to protect Taiwan's most vital interests-security from mainland power and continued economic and political development, and avoid great power conflict and escalation of regional tension by employing more or less the same Taiwan policy that has worked well over the past decades of years.[18]

\section{Nuclear Proliferation}

Chinese weapons exports have drawn much attention from critics of U.S. China policy. It is true that Chinese commercial enterprises have exported chemical weapon materiel [19]. But it is also true that its weapon proliferation policy is in substantive compliance with all international arms control agreements.

Since the end of the Cold War, and with the partial exception of its strategic relationship with Pakistan, China has not exported a single missile, transferred any nuclear technology, or engaged in proliferation of chemical weapon raw materials in violation of any international arms control regime. Contrary to several reports, China has not exported the M-9 missile to Syria. Its missile exports to the Middle East have consisted solely of short-range missiles that are not covered by the Missile Technology Control Regime (MTCR). Its cooperation with Algeria in nuclear energy, which dates back to the mid-1980s, has been under the continuous inspection of the International Atomic Energy Agency. In 1995 Beijing canceled its nuclear energy project with Iran. Its 1996 ring magnet transfer to Pakistan did not violate the Nuclear Non-Proliferation Treaty (NPT). China's policy on chemical weapon proliferation has been equally compliant.

China's most serious proliferation activities have been its nuclear assistance to Pakistan in the 1980s and its missile transfers to Pakistan in the 1990s. But just as post-Cold War U.S. weapons and technology transfers to Britain and Japan reveal that Washington engages in nuclear and missile proliferation when it suits its interests, Chinese missile transfers to Pakistan reflect its security interests. In some respects, China's Pakistan policy may fairly be compared to American indulgence toward Israel's nuclear weapons [20] Needlessly, just as Washington does not want its support for Israel to jeopardize its relations with Arab countries, Beijing does not want its support for Pakistan to derail its efforts to improve relations with India.

But the United States should avoid the conceit that a given mode of behavior can be wrong for every other country in the world but still right for the United States because of the purity of its motives. There is no reason to assume that China's motives in its relations with Pakistan turn on a different sort of reasoning - and we have every reason to think that, by the way, had the United States acted as a truly ally to Pakistan, much of what China provides that country would have been rendered unnecessary.

Overall, Chinese policy has supported the development of the global nonproliferation order. China has progressively joined international arms control agreements. In 1992 it 
formally joined the NPT. In 1996, despite the implications for its unreliable nuclear deterrent and grumbling from the PLA, Beijing signed the Comprehensive Test Ban Treaty. Over PLA objections, it has also signed and ratified the Chemical Weapons Convention, and agreed to the Land Mine Protocol to the Convention on Inhumane Weaponry. Recently, Chinese leaders have expressed interest in joining the Zangger Group, the export arms control of the NPT. Chinese participation in these regimes reflects American success at pressuring Beijing to accept global responsibility for controlling proliferation, even at a cost to China's own interests.

There is important arms control regimes from which China are shut out, including the MTCR and the Washington Group, which oversee conventional weapons exports. It is America that has blocked Chinese participation. Chinese absence from the MTCR is most troubling. Washington can have but limited confidence that Beijing will refrain from missile proliferation when it is a party neither to the original negotiations nor to subsequent adjustments to the MTCR. Even in these circumstances, Chinese exports to Pakistan stand as its only violation of the MTCR. As in any bilateral relationship, contemporary or historical, China is inclined to retaliate when American violations of U.S.-China agreements undermine its interests. This is not roguish but realistic.

In the non-nuclear realm, the United States does not oppose proliferation of missiles because they are "weapons of destruction," but they are the only delivery system against which the United States has no defense. But for most countries, U.S. F-16s, which Washington sells freely, are more threatening and more destructive than a Chinese M-11 missile. It is not at all clear that U.S. arms exports are any less "destabilizing" than Chinese exports.

Obviously, Chinese exports of weapons not covered by arms control regimes could undermine U.S. interests. But so far the impact has been minimal. Exports of low-technology short-range cruise missiles and chemical weapons precursors to Iran do not enhance Iran's ability to contend with the U.S. Navy or Air Force as much as they undermine American diplomatic efforts to enforce dual containment. But here China's record is not much different from that of many other countries, including several U.S. allies. The most flagrant challenge to Washington's dual containment policy with respect to Iraq comes not from China but from France, Turkey, and Russia, all of whom have strained to lighten the sanctions for financial reasons. Meanwhile, Japan and the members of the European Union trade with Iran as they do with any other country, and greatly resent U.S. efforts to stop them from doing so. German dual-use technology exports to Iran continue unchecked. This deal is more important to Tehran than anything that China provides.

China's record is far from perfect when it comes to arms dealing, but it is not the flagrant violator that it is often represented as being. Its more controversial exports reflect legitimate security interests rather than predatory political or opportunistic commercial interests. Moreover, some Chinese violations reflect not central government policy but rather
Beijing's limited control over economic enterprises and its inability to establish an effective export control regime.

With special reference to the Middle East, the most sensitive area in which Chinese behavior has been criticized, China has for the most part respected U.S. interests, and it has not done so without cost to itself. China has no inherent reason to refrain from proliferation to regions outside East Asia; since such countries cannot harm China directly, it might simply have allowed economic interests to drive its export policy. Instead, China has accommodated U.S. policy because both Bush and Clinton administration effectively combined coercive threats with constructive diplomacy. Since China's first missile exports to the Middle East in 1988, the systematic application of limited and well-targeted sanctions has persuaded Chinese leaders that Washington pays close attention to these PRC exports, and the exports that violate international regimes or harm U.S. interests risk disrupting U.S.-China cooperation. At the same time, the continuation of engagement in other areas has worked to convince Chinese leaders that cooperation with the United States is still feasible and worthwhile. The net result is that U.S. policy has compelled Beijing to comply with international arms control regimes and cooperate with U.S. interests more generally than might have been expected [21].

\section{CONCLUSION}

Ever since the establishment of formal diplomatic relationships, there are tensions between the two countries, due to the difference in the politics, ideology, economic interests and traditional values and many other factors. The two countries believe in two different political ideologies. After the collapse of the Soviet Union, China has become the biggest socialist country in the socialist camp. After China has taken the reform and opening-up policy, America has adopted different policies of not only coordination, but also containment. George w. bush, Bill Clinton introduced unilateralism and Obama introduced bilateralism, etc.

In 1999 the U.S. bombed the Chinese embassy in Yugoslavia, causing serious damage. The United States breached the UN charter and the relationship criterion with other nations, and overran other countries' sovereignty. This incident seriously affected the relationship and friendship between the two countries and the two peoples. Chinese government defended the sovereignty and dignity of China against United States-led NATO and showed the world that China is not an easy prey, not the disgrace of the Chinese nation.

With the rapid development of economy, China has groped a socialist road peculiar to its own characteristics, and practice has proved the correctness of this road. With the rapid development of globalization, especially the intensity of economic integration, cooperation and win-win policy, China has risen to a power of global economy; it commands a huge market of natural resources and human resources. So United States needs China to propel its national economy; at the same time, China's economic development needs the market of the United States.

Adopting the neo-realist politics, China performs the international politics of peaceful coexistence, mutual respect, 
mutual benefit and win-win policy. China does not hope to see conflict, confrontation, mutually hostile to each other. Although the United States has sent a positive echo, American doesn't expect to see the rise of a socialist China while it needs China to help it out of economy plight.

The Taiwan problem raises the most sensitive and dangerous issues, yet even here Beijing and Washington have established a way to satisfy their respective interests without undermining cooperative relations.

According to the theory of Neo-realism, the comprehensive national strength and international status of the US and China are changing constantly and deciding their positions in global structure to some extent. And their comprehensive national strength and international status further have a profound impact on the relationship among global states and international relationship. Formation and development of Sino-US strategic relationship is the concrete expression of neo-realism. The Bush administration built strategic partnerships with China after the 9.11 and the Obama administration declare that United States supports free trade and is committed to expanding trade ties with China.

China and the United States are more closely linked in all the aspects of economic life. As the United States' largest creditor, China is the important guarantee to help United States out of economic crisis, and more than half of the world's top 500 enterprises in the United States have settled in China and helped China to develop. The two countries should intensify mutual exchange, enhance cooperation, and seek mutual benefits and win-win policy instead of pursuing unilateral policies and implementing trade protectionism.

The common interests between China and the United States outweigh their numerous divergences. The existence of some differences and frictions can be solved through consultation on an equal footing. The two countries have broad prospects in military, law enforcement, science and technology, culture, education and other fields of education cooperation. In the fight against terrorism, nuclear nonproliferation, bird flu, energy, environmental protection, disaster relief and other important aspects, the dialogue and cooperation are also in line with the common interests of both sides. The Korean Peninsula nuclear issue promotes the six parties to hold talks to achieve a peaceful solution. Both sides work together to solve the Iranian nuclear issue to safeguard world peace. Stable development of Sino-US relations helps China to seize a good opportunity to develop national economy and establish the sustainable development of a harmonious society. Chinese development meets the common interests to build a lasting peace, common prosperity and harmonious world.

The rise of China is made against the background of the whole Asian prosperity. American strategy is universal sunshine policy that all the Asian countries prosper economically and maintain a relative stability so that American interests can be maximized. While China becomes a power in Asia, India and Japan are also the two powers in Asia. The possibility that China and the United States will have violent conflicts is less and less as the two have stable diplomatic relations for over 30 years. China share common interests with America in many sensitive issues like the Korean Peninsula nuclear issue.

The South China Sea Island chain concerns American global strategic interests and its credit among its alliance countries. The control of the South China Sea Island means the control of China as Chinese commercial activities turn to the Pacific Ocean and the Indian Ocean. So America will continue to exert its military existence in the Pacific Ocean to ensure its smooth navigation and its containment of china. To promote economic development and improve people's lives has always been China's central task on the way of the economic and social development. China will unswervingly follow the route of peaceful development and strive for a peaceful international environment to develop itself to promote world peace and development.

There are both common interests and differences between China and the United States. At present, China and the United States will need to consider the common interests and goals and reduce mutual conflicts to reach a win-win situation. The road for both sides to set up a constructive strategic partnership is long and tough.

\section{REFERENCES}

[1] Xiyuan Jiang, and Lizhong $\mathrm{Hu}$, "TheTheoretical Background and Restrictions of Bush Government's China Policy," International Observation, 2001(6), pp 10-14. (references)

[2] Dougherty, James E, Contending Theories of international relations: A comprehensive Survey . Beijing: Peking University Press, 2000, pp4-16.

[3] Duncan, W. Raymond, World Politics in the 21st Century. New York: Pearson Longman, 2002, pp 35-37.

[4] Eugene, R.Wittkopf and Christopher, M.Jones, The Future Of American Foreign Policy. Beijing: Peking University Press, 2003, pp 26-37.

[5] Goldstein, Joshua S, International relations. Beijing: Peking university Press, 2003, pp 56-77.

[6] Helen Purkitt, World Politics. Dubuque, IA: McGraw-Hill Contemporary Learning Series, 2010, pp 2-19.

[7] Jentleson, Bruce W, American Foreign Policy - the dynamics of choice in the 21st century. New York: Norton, 2000, pp 40-45.

[8] Kernell, Samuel, The Logic of American Politics. Washington, D.C: CQ Press, 2006, pp 60- 70.

[9] Jisi Wang, The World in the Eyes of Chinese Scholar. Vol. 4. China Diplomacy. Beijing: New World Publicing House, 2007, pp 79-89.

[10] Weibin Zhu, Theodore Roosevelt and China. Tianjin: Tianjin Ancient Book Publishing House, 2005, pp 90-111.

[11] Water Russell Mead, American Forengn Policy and How it Changed the World. Beijing: Zhongxing Publishing House, 2003, pp 80-91.

[12] James Mayall, World Politics. Beijing: China Compiling and Translating House, 2009, pp 98-101

[13] Hans J. Morgenthau, Politics among Nations. Beijing: Beijing University Publishing House, 2004, pp 54-87.

[14] Zhaoying Han, American Politics and Its Foreign Policy. Tianjin: Tianjin People Publishing House, 2007, pp 89-90.

[15] Zhongping Feng, "The New Features of Interaction between Europe and America and Its tendency," China Review, 2002, (06), pp 23-25. (references)

[16] Haijun Tang, "Where will Euro-US relations go," Contemporary World , 2001,(7), pp 9-11. (references)

[17] Yaowei Li, "Investigation of American Alliance Policy after Cold War," International Forum, 2003, (02), pp 43-56. (references) 
[18] Zhuji Zhang, "Cooperation and Disagreement," People Daily, 2002.5.29, pp 3. (references)

[19] Yuanyuan Zheng, "European Power Dream," People Daily, 2001.7.13, pp 7. (references)

[20] Gang Zhou, "European Security Studies after Cold War: A Constructivist Perspective," Huazhong Normal Univerity Academic Journal, 2007, (1) , pp 34-50 . (references)

[21] Haining Cui, "A Debate on American National Security Strategy after Cold War," Shangdong Normal University Academic Journal, 2005, 50 (2), pp 114-116. (references) 